Published in final edited form as:

Semin Nephrol. 2010 November ; 30(6): 627-634. doi:10.1016/j.semnephrol.2010.09.010.

\title{
Chronic kidney disease after hematopoietic stem cell transplantation
}

\author{
Eric P Cohen, $\mathbf{M D}^{1}$, Priya Pais, $\mathbf{M D}^{2}$, and John E Moulder, $\mathrm{PhD}^{3}$ \\ ${ }^{1}$ Department of Medicine, Medical College of Wisconsin Milwaukee, WI \\ 2 Department of Pediatrics, Medical College of Wisconsin Milwaukee, WI \\ ${ }^{3}$ Department of Radiation Oncology Medical College of Wisconsin Milwaukee, WI
}

\begin{abstract}
Acute and chronic kidney diseases occur after hematopoietic stem cell transplantation. These are caused by the transplant itself, and the complications of transplant. Recent estimates show that near 15\% of subjects undergoing HSCT will develop CKD, which is a complication rate that can affect outcome and reduce survival. Investigation of the causes of CKD is needed, as are ways to prevent, mitigate and treat it.
\end{abstract}

\section{Keywords}

Hematopoietic stem cell transplant; Chronic kidney disease; Radiation nephropathy; Prevention; Mitigation; Treatment

\section{Introduction}

In the 1970s, only a handful of patients underwent hematopoietic stem cell transplant (HSCT, bone marrow transplant or "BMT") and their 100 day survival was $50 \%$ or less (1). By the mid-1980s, over 5,000 HSCT were done yearly, and the five year survival after HSCT was up to $50 \%$, depending on the severity of the underlying cancer $(2,3)$. Now, over 20,000 HSCT are done per year, and the five year survival is over $50 \%$ for many treated cancers (www.cibmtr.org). Thus, long-term complications of HSCT were almost irrelevant 30 years ago, but today they must be known.

\section{Complications of HSCT}

Complications are those of disease - the risk of relapse - and those of treatment - the risks of graft versus host disease, for instance. Some organ toxicities have a clear pathogenesis, for instance the hypogonadism that is caused by chemotherapy and/or irradiation. Others, such as lung disease, could be due to chemo-irradiation treatments, compounded by the effects of superimposed infection. Telomere shortening of blood cells could relate to the

Corresponding author Dr Eric P Cohen Zablocki VA Medical Center 5000 W National Ave Milwaukee, WI 53295 Tel 414-384-2000 Fax 414-383-9333 Eric.Cohen2@va.gov.

Publisher's Disclaimer: This is a PDF file of an unedited manuscript that has been accepted for publication. As a service to our customers we are providing this early version of the manuscript. The manuscript will undergo copyediting, typesetting, and review of the resulting proof before it is published in its final citable form. Please note that during the production process errors may be discovered which could affect the content, and all legal disclaimers that apply to the journal pertain. 
replicative stress of the transplant itself (4). The HSCT patient will have a complex presentation.

Kidney disease after HSCT was not mentioned in the 1975 paper of Thomas et al (1). The first report of chronic kidney disease after CKD was in 1978 (5). By the 1980s, a number of case reports and series documented its occurrence, with emphasis on the relation to total body irradiation (TBI) used just before the HSCT (6). Still, chronic kidney disease was not mentioned in a 1991 review of adult survivors of HSCT (7). Now, end-stage-renal disease after HSCT has its own data entry box on the 2728 medical evidence form sent to the Center for Medicare and Medicaid Services (CMS) at the start of dialysis.

\section{Epidemiology}

Ellis et al created a synthetic analysis in which he carefully identified all reports of CKD after HSCT up to February 2007(8). An aggregate rate of CKD of 17\% in subjects surviving more than 100 days after HSCT is reported. In addition, the data show an average decline in the estimated GFR of $25 \mathrm{ml} / \mathrm{min}$, in the reports summarized by Ellis. Using reports of CKD after HSCT that date from 2007 to the present (9-16), we find a similar occurrence rate in both adults and children (figure 1). These reports also show that CKD after HSCT occurs worldwide. There are varying definitions of CKD in these reports, and the time of reporting is also variable. Nonetheless, there appears to be ongoing occurrence of this complication of HSCT. By way of comparison, the occurrence of CKD is a mere $1 \%$ in subjects using lithium, a well-known cause of renal injury (17). The rate of CKD after HSCT appears to be much higher than $1 \%$. CKD after HSCT can progress to end-stage-renal disease, which may be rare compared to more common causes of ESRD, but it occurs at an age and sex matched rate that is almost twenty times that of the general population (18).

\section{Role of radiation}

The connection to TBI is supported by the studies using a rat model of TBI-HSCT in which the major lethal toxicity is renal failure (19). The single fraction $10 \mathrm{~Gy}$ dose that causes this injury is the same as that which can cause it in humans, has the same 3 to 6 months latency from irradiation to injury, and a very similar histology, with glomerular mesangiolysis. Moreover, partial kidney shielding at the time of TBI has reduced the occurrence of chronic kidney disease at our center (20).

The animal and human data provided the rationale for further study, centered around the radiation injury. The animal model uses a TBI followed by a syngeneic transplant in rats that are housed in a high security barrier, and thus it avoids the confounding effects of graft versus host disease or infection. Multiple aspects of its pathogenesis have been tested for causality in this model, as summarized in table 1 (21-28).

Of these hypothesized pathogenic mechanisms, fibrosis, the renin-AII system, and vascular injury have not been disproven, to date. The others are either absent or do not play a causal role. Fibrosis has long been recognized as a prominent feature in radiation nephropathy, throughout the kidney and more recently at the glomerulotubular neck, where it could play a key role in affecting function. Captopril stabilizes that neck fibrosis in association with preservation of function. (24). Because of the beneficial effects of angiotensin converting enzyme inhibitors and angiotensin type 1 receptor blockers in this model, we expected to find activation of the renin-AII system in radiation nephropathy. That has not been found (21). From renin to AII, systemic as well as intrarenal, and the AII receptors themselves have not been found to be changed in experimental radiation nephropathy (29). Nonetheless, the role of the renin-AII system is confirmed because AII infusion exacerbates radiation nephropathy, and suppression of the renin-AII system is beneficial (21). Vascular injury has 
long been blamed for radiation late effects, and mitigation of vascular injury is correlated with the benefit of captopril in radiation nephropathy (23). These three pathways -fibrosis, the renin-AII system, and vascular injury - are thus encouraging for further study, and improved treatments.

\section{Membranous nephropathy}

The first case of membranous nephropathy after HSCT was reported in 1989 (30). A link with graft-versus-host disease has been postulated, which could occur via an antibodymediated mechanism. Since 2007, at least ten more have been reported (31-33). The median time of kidney biopsy in these cases was 28 months after HSCT, and the median daily proteinuria was 8 grams. This latency of time-to-diagnosis is later than that of typical radiation-related "BMT nephropathy", which is about 9 months after the HSCT (34), and the amount of proteinuria is much higher, being on average only 2.5 grams/day in BMT nephropathy. Both myeloablative and non-myeloablative HSCT have been associated with membranous nephropathy. Non-myeloablative BMT does not ablate host plasma cells, which could play a pathogenic role (35).

\section{Other causes of CKD}

Yet not all CKD after HSCT can be blamed on TBI. The variability of kidney biopsy and autopsy findings by itself shows this (36). Membranous nephropathy, focal glomerulosclerosis, minimal change disease, polyoma nephritis, and thrombotic microangiopathy have each been reported as causes of CKD after HSCT (36), but only the latter is caused by TBI. Moreover, CKD occurs after non-myeloablative HSCT, in which the 2 Gy dose of TBI is well below the dose range that may cause radiation nephropathy (37). Clinical analyses have shown the association of acute kidney injury after HSCT with subsequent CKD, albeit without clarifying the mechanism of this association (37). Focused study of each of these causes of CKD is warranted, much as has been done for radiation. To these likely contributors one speculate on the role of a family history of renal disease, or even low birthweight. The non-muscle myosin heavy chain 9 (MYH9) polymorphisms predispose to glomerular disease, but this appears to depend on a second hit (38). These and other gene polymorphisms could explain why a similar "hit" - the interventions of the HSCT - causes renal disease in some but not all patients. One can hypothesize a similar effect of low birth weight. Thus, low birth weight could predispose to kidney disease after HSCT because the subject with low birth weight may have fewer nephrons (39).

\section{Role of underlying renal disease}

Until recently, pre-existing renal disease was an exclusion criterion for bone marrow transplantation. This is no longer the case, especially for diseases such as multiple myeloma. Such patients may undergo autologous or allogeneic marrow transplants that may slow progression of their myeloma yet leave them with substantial residual renal impairment. Because the age limit for HSCT is increasing, it is likely that more and more subjects with disease or age-related renal impairment may undergo HSCT (40). One can predict future increases in the occurrence rates of significant CKD after HSCT.

\section{Clinical presentation}

CKD after HSCT may not be recognized early, because of the competing clinical priorities. Thus, treatment of graft versus host disease and surveillance for recurrent disease usually have a higher priority than does the diagnosis of renal injury. In addition, because of chronic illness, bodily creatinine production may decline, such that the serum creatinine may be deceptively "normal". Proteinuria may be missed because urinalysis is not a routine test. The 
patients will have a number of co-morbidities, much like non-HSCT patients ten or twenty years older than them. There will have been past chemotherapy, past infectious episodes, and there is a long list of past and present medications. There may be past or present graft versus host disease $(\mathrm{GVH})$. The time of presentation can be a clue to cause, 9 months from HSCT being the median time for BMT nephropathy, and 28 months being the median time for membranous nephropathy. The physical exam may show edema or hypertension.

Absence of hypertension points to interstitial rather than glomerular disease. Retinitis can occur, and could suggest a complication of irradiation (41). There may be proteinuria, which if in the nephrotic range would point to nephrotic syndromes rather than thrombotic microangiopathy. Nephrotic range proteinuria associated with chronic GVH suggests membranous nephropathy (33). Azotemia is non-specific, but the rate of decline of GFR may point to thrombotic microangiopathy, in which it is ten times as fast as that of common causes of progressive renal failure (34). Hypophosphatemia with an elevated fractional excretion of phosphorus could suggest tubular injury.

\section{Role of kidney biopsy}

The typical case of "BMT nephropathy" occurs at 6 to 12 months after HSCT, in a subject who had total body irradiation in sufficient dose at the time of the HSCT, and presents with azotemia, hypertension, and an anemia that is disproportionate to the degree of azotemia (34). A kidney biopsy to show the typical mesangiolysis would not be needed in such a case. A less specific presentation might require biopsy, of which the typical feature of mesangiolysis is shown in figure 2. Nephrotic-range proteinuria could justify kidney biopsy to differentiate minimal change from membranous nephropathy or focal glomerulosclerosis. Red cell casts on urinalysis would point to a glomerulonephritis, for which the treatment may be different.

\section{Management}

Cure of CKD after HSCT is as unlikely as it is in the general population. Still, if a specific cause can be identified, for instance use of pamidronate that causes focal glomerulosclerosis, proteinuria can regress and progression may stop if the drug is stopped (42). Stopping calcineurin inhibitors may be necessary in other patients, but alternatives are limited in subjects with graft versus host disease. Prednisone can reverse minimal change disease. Immunosuppression may be beneficial for minimal change or membranous nephropathy as it is in the general population. Rituximab has been used with benefit, and could act directly to suppress dysregulated B-calls of the chronic GVHD that has been associated with membranous nephropathy $(32,43)$. Control of the blood pressure and antagonism of the renin-angiotensin system are indicated for hypertensive CKD as they are in the general population. Antagonists of the renin-angiotensin system are very effective in prevention, mitigation, and treatment of experimental radiation nephropathy, and they are our standard of care for humans with BMT nephropathy. Slowing of advanced progressive CKD can be achieved (figure 3 ).

\section{Outcome}

Complete loss of kidney function and the need for dialysis or kidney transplantation does occur. The age and sex matched rate of ESRD per million population is much higher for subjects who have had a HSCT than it is for the general population (18). ESRD after HSCT is not confined to the USA (16). Anemia may occur and can be disproportionately severe in subjects with BMT nephropathy, in relation to their renal function, and has been linked to erythropoietin deficiency $(34,44)$. Supplemental erythropoietin is effective in its treatment. Progressive renal failure may occur despite one's best efforts. Survival on dialysis is poor (45). This is probably due to the many co-morbidities of these patients. 
While these severe outcomes cause major disability and death, CKD itself may be an independent risk factor that reduces survival after HSCT (46). That is further justification for the careful study of each of the various causes of renal injury after CKD, so that they can be prevented, mitigated, and treated.

\section{Role of kidney transplant}

Kidney transplantation is an option for these patients, provided that co-morbidities do not prohibit it. Four recent single center series have reported a total of 27 cases (47-50). Of these, 9 received a kidney from their marrow donor, and thus required no immunosuppression. When a kidney is from a deceased donor, we advise use of an overall immunosuppression dose that is half the usual, because the recipient's marrow may not be fully functional. The United Network for Organ Sharing (UNOS) does not record the presence of a previous HSCT in subjects getting listed for or undergoing kidney transplant, so that the national occurrence rate is not known.

\section{Mitigation}

The severity of this complication of CKD after HSCT and our animal data lead us to perform a randomized controlled trial of captopril compared to placebo to mitigate the occurrence of chronic renal failure after HSCT at our center (51). Included in this study were adults and children undergoing radiation-based HSCT. Captopril was used in a mitigation mode, i.e. started at engraftment of the new marrow. This is several weeks after the radiation but well before evidence of chronic renal injury. Such use of an angiotensin converting enzyme inhibitor in mitigation has been amply confirmed in a rat model $(29,52)$. It also avoids the potential adverse effects of using captopril at the time of host marrow ablation (53). Our study showed reduction in the occurrence of the BMT nephropathy syndrome in those on captopril compared to placebo, and better patient survival in those on captopril compared to placebo. These favorable trends did not reach statistical significance. At the same time as this study was in progress, additional subjects underwent radiationbased HSCT but did not enroll in the captopril study. They form a control group that was not on the study drug. When one combines these subjects with the placebo group, thus creating a larger "no-drug" group, comparison of the no-drug group to the those on captopril and a longer follow-up time showed a significantly better patient survival in those on captopril $(\mathrm{p}=0.03)$. These results would require confirmation before they could be adopted for other HSCT patients, and they may not apply at all to HSCT conditioning regimens that do not use radiation or that use it at a low dose.

\section{Conclusion}

We have summarized the occurrence of chronic kidney disease that may complicate HSCT. It can take many forms, of which one is a congener of radiation nephropathy. Both treatment and mitigation of this problem appear possible, but end-stage-renal-disease continues to occur. Ongoing use of HSCT and extension of its use in older subjects will add to the numbers of patients with CKD after HSCT. Awareness and focused study of renal injury after HSCT is needed.

\section{Acknowledgments}

Supported in part by NIH/NIAID 1U19AI067734 


\section{References}

1. Thomas E, Storb R, Clift RA, Fefer A, Johnson FL, Neiman PE, et al. Bone-marrow transplantation (first of two parts). N Engl J Med Apr 17;1975 292(16):832-43. [PubMed: 234595]

2. Armitage JO. Bone marrow transplantation. N Engl J Med Mar 24;1994 330(12):827-38. [PubMed: 8114836]

3. Ash RC, Casper JT, Chitambar CR, Hansen R, Bunin N, Truitt RL, et al. Successful allogeneic transplantation of T-cell-depleted bone marrow from closely HLA-matched unrelated donors. N Engl J Med Feb 22;1990 322(8):485-94. [PubMed: 2300120]

4. Wynn RF, Cross MA, Hatton C, Will AM, Lashford LS, Dexter TM, et al. Accelerated telomere shortening in young recipients of allogeneic bone-marrow transplants. Lancet Jan 17;1998 351(9097):178-81. [PubMed: 9449873]

5. Kamil ES, Latta H, Johnston WH, Feig SA, Bergstein JM. Radiation nephritis following bone marrow transplantation. Kidney Int 1978;14:713.

6. Antignac C, Gubler MC, Leverger G, Broyer M, Habib R. Delayed renal failure with extensive mesangiolysis following bone marrow transplantation. Kidney Int Jun;1989 35(6):1336-44. [PubMed: 2671466]

7. Wingard JR, Curbow B, Baker F, Piantadosi S. Health, functional status, and employment of adult survivors of bone marrow transplantation. Ann Intern Med Jan 15;1991 114(2):113-8. [PubMed: 1984385]

8. Ellis MJ, Parikh CR, Inrig JK, Kanbay M, Patel UD. Chronic kidney disease after hematopoietic cell transplantation: A systematic review. Am J Transplant Nov;2008 8(11):2378-90. [PubMed: 18925905]

9. Gronroos MH, Bolme P, Winiarski J, Berg UB. Long-term renal function following bone marrow transplantation. Bone Marrow Transplant Jun;2007 39(11):717-23. [PubMed: 17401393]

10. Leung W, Ahn H, Rose SR, Phipps S, Smith T, Gan K, et al. A prospective cohort study of late sequelae of pediatric allogeneic hematopoietic stem cell transplantation. Medicine (Baltimore) Jul; 2007 86(4):215-24. [PubMed: 17632263]

11. Abboud I, Porcher R, Robin M, de Latour RP, Glotz D, Socie G, et al. Chronic kidney dysfunction in patients alive without relapse 2 years after allogeneic hematopoietic stem cell transplantation. Biol Blood Marrow Transplant Oct;2009 15(10):1251-7. [PubMed: 19747632]

12. Al-Hazzouri A, Cao Q, Burns LJ, Weisdorf DJ, Majhail NS. Similar risks for chronic kidney disease in long-term survivors of myeloablative and reduced-intensity allogeneic hematopoietic cell transplantation. Biol Blood Marrow Transplant Jun;2008 14(6):658-63. [PubMed: 18489991]

13. Choi M, Sun CL, Kurian S, Carter A, Francisco L, Forman SJ, et al. Incidence and predictors of delayed chronic kidney disease in long-term survivors of hematopoietic cell transplantation. Cancer Oct 1;2008 113(7):1580-7. [PubMed: 18704986]

14. Kersting S, Verdonck LF. Chronic kidney disease after nonmyeloablative stem cell transplantation in adults. Biol Blood Marrow Transplant Apr;2008 14(4):403-8. [PubMed: 18342782]

15. Saddadi F, Hakemi M, Najafi I, Moghadam K, Ghavamzadeh A, Jahani M, et al. Chronic kidney disease after hematopoietic cell transplantation: Frequency, risk factors, and outcomes. Transplant Proc Sep;2009 41(7):2895-7. [PubMed: 19765466]

16. Ando M, Ohashi K, Akiyama H, Sakamaki H, Morito T, Tsuchiya K, et al. Chronic kidney disease in long-term survivors of myeloablative allogeneic haematopoietic cell transplantation: Prevalence and risk factors. Nephrol Dial Transplant Jan;2010 25(1):278-82. [PubMed: 19762604]

17. Bendz H, Schon S, Attman PO, Aurell M. Renal failure occurs in chronic lithium treatment but is uncommon. Kidney Int Feb;2010 77(3):219-24. [PubMed: 19940841]

18. Cohen EP, Drobyski WR, Moulder JE. Significant increase in end-stage renal disease after hematopoietic stem cell transplantation. Bone Marrow Transplant May;2007 39(9):571-2. [PubMed: 17351643]

19. Moulder JE, Fish BL. Late toxicity of total body irradiation with bone marrow transplantation in a rat model. Int J Radiat Oncol Biol Phys Jun;1989 16(6):1501-9. [PubMed: 2656600] 
20. Lawton CA, Cohen EP, Murray KJ, Derus SW, Casper JT, Drobyski WR, et al. Long-term results of selective renal shielding in patients undergoing total body irradiation in preparation for bone marrow transplantation. Bone Marrow Transplant Dec;1997 20(12):1069-74. [PubMed: 9466280]

21. Cohen EP, Fish BL, Moulder JE. The renin-angiotensin system in experimental radiation nephropathy. J Lab Clin Med Apr;2002 139(4):251-7. [PubMed: 12024113]

22. Cohen EP, Fish BL, Irving AA, Rajapurkar MM, Shah SV, Moulder JE. Radiation nephropathy is not mitigated by antagonists of oxidative stress. Radiat Res Aug;2009 172(2):260-4. [PubMed: 19630531]

23. Cohen EP, Molteni A, Hill P, Fish BL, Ward WF, Moulder JE, et al. Captopril preserves function and ultrastructure in experimental radiation nephropathy. Lab Invest Sep;1996 75(3):349-60. [PubMed: 8804358]

24. Cohen EP, Regner K, Fish BL, Moulder JE. Stenotic glomerulotubular necks in radiation nephropathy. J Pathol Mar;2000 190(4):484-8. [PubMed: 10699999]

25. Datta PK, Moulder JE, Fish BL, Cohen EP, Lianos EA. TGF-beta 1 production in radiation nephropathy: Role of angiotensin II. Int J Radiat Biol Apr;1999 75(4):473-9. [PubMed: 10331853]

26. Moulder JE, Fish BL, Regner KR, Cohen EP. Angiotensin II blockade reduces radiation-induced proliferation in experimental radiation nephropathy. Radiat Res Apr;2002 157(4):393-401. [PubMed: 11893241]

27. Sharma M, Sharma R, Ge XL, Fish BL, McCarthy ET, Savin VJ, et al. Early detection of radiationinduced glomerular injury by albumin permeability assay. Radiat Res Mar;2001 155(3):474-80. [PubMed: 11182799]

28. Lenarczyk M, Cohen EP, Fish BL, Irving AA, Sharma M, Driscoll CD, et al. Chronic oxidative stress as a mechanism for radiation nephropathy. Radiat Res Feb;2009 171(2):164-72. [PubMed: 19267541]

29. Cohen EP, Fish BLMJE. Mitigation of radiation injuries via suppression of the renin-angiotensin system: Emphasis on radiation nephropathy. Curr Drug Targets. 2009 in press.

30. Muller GA, Muller CA, Markovic-Lipkowski J, Bross-Bach U, Schmidt H, Ehninger G, et al. Membranous nephropathy after bone marrow transplantation in ciclosporin treatment. Nephron 1989;51(4):555-6. [PubMed: 2662038]

31. Chan GS, Lam MF, Au WY, Chim S, Tse KC, Lo SH, et al. Clinicopathologic analysis of renal biopsies after haematopoietic stem cell transplantation. Nephrology (Carlton) Jun;2008 13(4):32230. [PubMed: 18221254]

32. Ferrannini M, Vischini G, Di Daniele N. Rituximab in membranous nephropathy after haematopoietic stem cell transplantation. Nephrol Dial Transplant Aug;2008 23(8):2700. 1; author reply 2701. [PubMed: 18385388]

33. Terrier B, Delmas Y, Hummel A, Presne C, Glowacki F, Knebelmann B, et al. Post-allogeneic haematopoietic stem cell transplantation membranous nephropathy: Clinical presentation, outcome and pathogenic aspects. Nephrol Dial Transplant May;2007 22(5):1369-76. [PubMed: 17255123]

34. Cohen EP, Lawton CA, Moulder JE, Becker CG, Ash RC. Clinical course of late-onset bone marrow transplant nephropathy. Nephron 1993;64(4):626-35. [PubMed: 8366991]

35. Srinivasan R, Balow JE, Sabnis S, Lundqvist A, Igarashi T, Takahashi Y, et al. Nephrotic syndrome: An under-recognised immune-mediated complication of non-myeloablative allogeneic haematopoietic cell transplantation. Br J Haematol Oct;2005 131(1):74-9. [PubMed: 16173966]

36. Chang A, Hingorani S, Kowalewska J, Flowers ME, Aneja T, Smith KD, et al. Spectrum of renal pathology in hematopoietic cell transplantation: A series of 20 patients and review of the literature. Clin J Am Soc Nephrol Sep;2007 2(5):1014-23. [PubMed: 17702721]

37. Weiss AS, Sandmaier BM, Storer B, Storb R, McSweeney PA, Parikh CR. Chronic kidney disease following non-myeloablative hematopoietic cell transplantation. Am J Transplant Jan;2006 6(1): 89-94. [PubMed: 16433761]

38. Bostrom MA, Freedman BI. The spectrum of MYH9-associated nephropathy. Clin J Am Soc Nephrol Jun;2010 5(6):1107-13. [PubMed: 20299374]

39. Luyckx VA, Brenner BM. Low birth weight, nephron number, and kidney disease. Kidney Int Suppl Aug;2005 (97):S68-77. (97). [PubMed: 16014104] 
40. Ljungman P, Bregni M, Brune M, Cornelissen J, de Witte T, Dini G, et al. Allogeneic and autologous transplantation for haematological diseases, solid tumours and immune disorders: Current practice in europe 2009. Bone Marrow Transplant Feb;2010 45(2):219-34. [PubMed: 19584824]

41. Bernauer W, Gratwohl A, Keller A, Daicker B. Microvasculopathy in the ocular fundus after bone marrow transplantation. Ann Intern Med Dec 15;1991 115(12):925-30. [PubMed: 1952488]

42. Cohen, EP. The assessment of kidney function. In: Cohen, EP., editor. Cancer and the kidney. 1st ed. Oxford University Press; Oxford: 2005. p. 1-16.

43. Reddy P, Johnson K, Uberti JP, Reynolds C, Silver S, Ayash L, et al. Nephrotic syndrome associated with chronic graft-versus-host disease after allogeneic hematopoietic stem cell transplantation. Bone Marrow Transplant Sep;2006 38(5):351-7. [PubMed: 16862167]

44. Vincent F, Costa MA, Rondeau E. Chronic renal failure: A nonmalignant late effect of allogeneic stem cell transplantation. Blood Oct 1;2003 102(7):2695. author reply 2695-6. [PubMed: 14504068]

45. Cohen EP, Piering WF, Kabler-Babbitt C, Moulder JE. End-stage renal disease (ESRD)after bone marrow transplantation: Poor survival compar ed to other causes of ESRD. Nephron Aug;1998 79(4):408-12. [PubMed: 9689155]

46. Cohen EP, Sumaili EK, Krzesinski JM, Delanaye P, Cavalier E, Beguin Y. Chronic kidney disease after hematopoietic stem cell transplantation: Incidence, risk factors, and survival. J Am Soc Nephrol 2009:20.

47. Butcher JA, Hariharan S, Adams MB, Johnson CP, Roza AM, Cohen EP. Renal transplantation for end-stage renal disease following bone marrow transplantation: A report of six cases, with and without immunosuppression. Clin Transplant Aug;1999 13(4):330-5. [PubMed: 10485375]

48. Hamawi K, De Magalhaes-Silverman M, Bertolatus JA. Outcomes of renal transplantation following bone marrow transplantation. Am J Transplant Mar;2003 3(3):301-5. [PubMed: 12614285]

49. Thomas SE, Hutchinson RJ, DebRoy M, Magee JC. Successful renal transplantation following prior bone marrow transplantation in pediatric patients. Pediatr Transplant Oct;2004 8(5):507-12. [PubMed: 15367289]

50. Beitinjaneh A, Burns LJ, Majhail NS. Solid organ transplantation in survivors of hematopoietic cell transplantation: A single institution case series and literature review. Clin Transplant. Nov 16;2009

51. Cohen EP, Irving AA, Drobyski WR, Klein JP, Passweg J, Talano JA, et al. Captopril to mitigate chronic renal failure after hematopoietic stem cell transplantation: A randomized controlled trial. Int J Radiat Oncol Biol Phys Apr 1;2008 70(5):1546-51. [PubMed: 18029109]

52. Moulder JE, Cohen EP. Future strategies for mitigation and treatment of chronic radiation-induced normal tissue injury. Semin Radiat Oncol Apr;2007 17(2):141-8. [PubMed: 17395044]

53. Davis TA, Landauer MR, Mog SR, Barshishat-Kupper M, Zins SR, Amare MF, et al. Timing of captopril administration determines radiation protection or radiation sensitization in a murine model of total body irradiation. Exp Hematol Apr;2010 38(4):270-81. [PubMed: 20116413] 


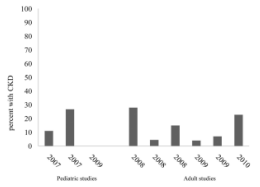

Figure 1.

The prevalence of chronic kidney disease after HSCT in children and adults. The pediatric studies are shown on the left, the adult studies on the right. The year of the study report is shown on the $\mathrm{x}$ axis, the percentage of subjects on the $\mathrm{y}$ axis. These data are for 2007 onwards, and from reports as cited (9-16). The arithmetic average for all studies is $13 \%$. 




Figure 2.

Photomicrograph of a kidney biopsy of a man who developed acute lymphocytic leukemia in 2009. He received a hematopoietic stem cell transplant (HSCT) from an HLA matched sibling after conditioning with total body irradiation (1200 cGy over 3 days). He developed hemolytic uremic syndrome at 5 months after HSCT. His serum creatinine increased when his calcineurin inhibitor was stopped, so a kidney biopsy was done. The arrow shows the characteristic mesangiolysis (Jones stain, 400x) 


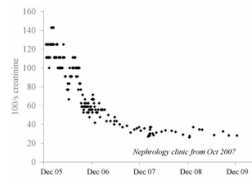

Figure 3.

The evolution of GFR as 100/s creatinine, for s creatinine in $\mathrm{mg} / \mathrm{dl}$, in another case of BMT nephropathy. The initial rapid decline of kidney function is evident. Use of captopril and control of the blood pressure has coincided with clear stabilization of the kidney function, albeit at a low level. 
Table 1

A summary of possible mechanisms of radiation nephropathy

\begin{tabular}{|l|l|}
\hline mechanism & reference \\
\hline Oxidative stress & $(22,28)$ \\
\hline Cell proliferation & $(26)$ \\
\hline TGF-beta & $(25)$ \\
\hline Glomerular permeability & $(27)$ \\
\hline Fibrosis & $(24)$ \\
\hline Renin-angiotensin system & $(21)$ \\
\hline Vascular injury & $(23)$ \\
\hline
\end{tabular}

